\title{
Mainstream educational enrollment for students with SEN in the EU
}

\author{
Garcia-Garcia, Fran J. \\ University of Valencia, Valencia, Spain \\ garfran6@uv.es \\ Lopez-Torrijo, Manuel \\ University of Valencia, Valencia, Spain \\ lopezm@uv.es \\ Gil-Linares, Gonzalo \\ University of Valencia, Valencia, Spain \\ gonzalopedagogia@gmail.com
}

\begin{abstract}
Inclusive education is a relevant goal of the EU agenda. The educational reform started up in 70 s has impacted on the current European educational enrollment. Regardless EU convergence, not every country has similar inclusion rates and that makes a multi-speed Europe in education, not as a political project but as a fact. After integration was overcome by inclusion and while inter and supranational declarations continue being written, we wonder on the mainstream educational enrollment rates for a better understanding of the European inclusive education. The rates of 28 countries have been analyzed. 25 of them are from the EU and 3 from the Schengen area. The dataset of the European Agency for Special Needs and Inclusive Education was used for country data collection. Then, data were processed and three scores were obtained: students with SEN relative to the total school aged children; those of them in separate classes (mainstream centers) relative to those in formal educational settings; and students in special schools relative to the total students with official decision of SEN. Descriptive, relative data of each country is reported comparing findings, both demographics and educational enrollment rates. Whereas countries such as Austria, Belgium or Germany seem to be less inclusive, others like Cyprus, Italy or Spain appear to be European models for achieve inclusive education. New European educational policy trends, research lines and implication for practice are discussed.
\end{abstract}

\section{Resumen}

La educación inclusiva es un objetivo importante en la agenda de la UE. La reforma educativa iniciada en los años 70 ha impactado en la actual matriculación educativa en Europa. Al margen de la convergencia de la Unión, no todos los países tienen tasas de inclusión similares y eso implica una Europa a diferentes velocidades, no como un proyecto político sino como un hecho. Después de que la integración fuera reformulada como inclusión y a la vez que se continúan redactando declaraciones inter y supranacionales, nos hemos preguntado acerca de las tasas de matriculación educativa para una mejor comprensión de la educación inclusiva europea. Han sido analizadas las tasas de 28 países. 25 de ellos pertenecen a la UE y 3 al área de Schengen. Se utilizó la base de datos de la European Agency for Special Needs and Inclusive Education para la recogida de datos por país. A continuación, se procesaron los datos y se obtuvieron tres puntajes: porcentaje de estudiantes con NEE respecto al total de niños en edad escolar; aquellos que están en unidades específicas (centros ordinarios) con relación a los que cursan itinerarios de educación normalizada; y porcentaje de estudiantes en centros de educación especial con relación al total de alumnos con NEE diagnosticadas. Los datos descriptivos y relativizados de cada país se reportan comparando los hallazgos, tanto demográficos, como referidos a la matriculación educativa. Mientras que países como Austria, Bélgica o Alemania parecen ser menos inclusivos, otros como Chipre, Italia o España son modelos europeos para alcanzar la educación inclusiva. Se debaten las nuevas tendencias de la política educativa europea, las líneas de investigación y las implicaciones para la práctica.

Keywords: inclusive education, special educational needs, Europe, registration.

Palabras clave: educación inclusiva, necesidades educativas especiales, Europa, inscripción. 


\section{INTRODUTION}

Inclusion is not a new framework for political and social action neither it is a pedagogical trend. The last decades have been influenced by the claim for this fundamental right to education for all. Far from being a solved, closed point in the EU agenda, Inclusive Education (IE) remains a goal both in politics and research. Politics and normative development in Europe will be displayed all along the text. As for research, many specialized meetings -such as the World Congress on Special Needs Education in Cambridge (Dec 2017) or the Inclusion International, 17th World Congress in Brimingham (May 2018)are good indicators for vouching the relevance of this topic.

\section{From normalization to integration}

In the 60s, authors from Northern Europe and North America began to mint the term 'normalization' regarding people with cognitive disability. N. B. Mikkelsen incorporated it to the Danish law in 1959 and, later, Nirge (1969) and Wolfensberger (1972) defined the term in greater depth. The overall idea was to get a normal life through normal means for people with disability as much as possible.

At the end of the next decade it was published the Warnock Report in the UK (Warnock, 1978). A normal life would be achieved integrating the students with special educational needs (SEN) into mainstream centers according to report conclusions. 'Integration' triggered an educational reform that extended all around the European systems.

The reform was almost parallel in Sweden (Normalization Law of 1968), Norway (Amendments to the Education Law of 1975), England (Special Education Law of 1970, 1976 and 1981), France (Orientation Law of 1975), Italy (Law of March 30th, 1971), Portugal (Law on the Reform of the Teaching System of 1973 and 1979) and, out of Europe, in the United States (Public Law 93/112 of 1973, General Law on Special Education of 1975 and 1977). The commitment to normalization in Denmark did not differentiate any specific law, but included special provision within the general legislation (parliamentary decision of 1969 and circular of August 1975).

\section{The first step to IE}

After integration failed in the majority of the European countries, 'inclusion' appeared to be a new approach. IE implies to remove learning and participation barriers for every pupil. That requires specialized and individualized services in a common space. Enrolling students with SEN in mainstream educational settings with appropriate services is, therefore, the first step to inclusion. It is not enough to make IE real, but otherwise isolation becomes the main barrier.

In this moment and ahead, IE emphasizes: [1] the basic right to education for all, [2] diversity as a value, [3] mainstream educational settings as the most realistic, natural and effective ones, [4] participation and coexistence as a goals of every educational process, [5] a functional, common and adapted curriculum, [6] meaningful, cooperative, constructivist and reflective learning and [7] the complete involvement of the educational community.

These were the conclusions of the Regular Education Initiative of North America in the later 80s, led by Stainback \& Stainback (1992), and afterward by Fulcher (2015); see also authors such as Slee in Australia, Ainscow, Barton, Booth and Tomilson in the UK, Ballard in New Zealand and Arnaiz, Echeita and Grau in Spain. Moreover, El is an attitude, a set of values and beliefs, a better way of living together (Armstrong, 1999).

Beyond the mainstream enrollment, the Index for Inclusion (Booth \& Ainscow, 2002) established three key areas to be improved in educational centers: culture, politics and practices for inclusion. This cover a wide range of aspects, since early detection and intervention to job placement and daily life skills. 


\section{An unfinished portrait}

IE is an ideal situation and, probably because of that, it is difficult to be completely reached. That is reflected by a number of inter and supranational documents. Table 1 shows some of them.

These conferences, declarations and even conventions transmit a clear message. Inclusion is a permanent claiming since 70 s and this goal has not been overcome yet.

Table 1. International and European documents for IE.

\begin{tabular}{|c|c|c|}
\hline Date & Organism & Document \\
\hline Dec 1971 & United Nations & Declaration on the Rights of Mentally Retarded Persons \\
\hline Mar 1990 & Unesco & World Conference on Education for All \\
\hline Jun 1991 & Unesco & Salamanca Statement \\
\hline Dec 1997 & European Parliament & Luxembourg European Council \\
\hline Mar 2000 & Unesco & International Consultative Forum on Education for All \\
\hline May 2001 & $\begin{array}{l}\text { World Health } \\
\text { Organization }\end{array}$ & $\begin{array}{l}\text { International Classification of Functioning, } \\
\text { Disability and Health }\end{array}$ \\
\hline Mar 2002 & European Congress & Madrid Statement \\
\hline Dec 2006 & United Nations & Convention on the Rights of Persons with Disabilities \\
\hline Nov 2008 & Unesco & International Conference on Education, 48th session \\
\hline May 2014 & Unesco & Mascate Agreement \\
\hline May 2015 & Unesco & Incheon Statement \\
\hline Nov 2017 & European Commission & European Pillars of Social Right \\
\hline
\end{tabular}

Source: own elaboration.

\section{Aim and research problem}

In the beginning of the new millennium it has been pointed up global objectives such as achieving universal primary education (United Nations, 2015). Facing this kind of challenges, we have selected the EU to analyze mainstream educational enrollment of students with SEN. Out of other exclusion situations like extreme poverty, digital gap, illiteracy, etcetera, we have focused on special needs derived from permanent disability.

The aim is to compare inclusion rates throughout the member states for a better understanding of the current impact of the 70 s educational reform in Europe. 


\section{METHOD}

Comparative method has been applied defining comparative units, variables and procedure.

\section{Units}

A list of the units is shown in Table 2. EU member states located in the dataset of the European Agency for Special Needs and Inclusive Education (Eadsne) were included. The Agency has also data from other countries of the Schengen area that were analyzed as a complement. Data from Belgium and the UK were differentiated by zones, as it was found in the database.

\section{Instruments}

The Eadsne descriptive stats (last modified Nov 8, 2016) were used for raw data collection. Other tests or instruments were not necessary.

\section{Variables}

Variables were school aged children (Var1), students with official decision of SEN (Var2), those of them in separate classes of mainstream centers (Var3), in formal educational settings (Var4) and enrolled in special schools (Var5).

Table 2. Comparative units.

\begin{tabular}{cccc}
\hline & EU member states & & Schengen area \\
\hline Austria & Germany & Portugal & Iceland \\
Belgium (Flemish) & Hungary & Slovakia & Norway \\
Belgium (French) & Ireland & Slovenia & Switzerland \\
Croatia & Italy & Spain & \\
Cyprus & Latvia & Sweden & \\
Czech Republic & Lithuania & UK (England) & \\
Denmark & Luxembourg & UK (Northern Ireland) & \\
Estonia & Malta & UK (Scotland) & \\
Finland & Netherlands & UK (Wales) & \\
France & Poland &
\end{tabular}

Source: own elaboration. 


\section{Procedure}

The Eadsne data were transferred to Microsoft Excel 2016 and transformed in quantitative cells.

Variables provided by the Agency were codified and relativized. General data such as students in formal educational settings or school aged children were used as denominators.

Subsequent relative variables were Var2/Var1, Var3/Var4 and Var5/Var2.

The International Standard Classification of Education (ISCED) was used for blocking ages and, then, findings were contrasted between the comparative units.

\section{RESULTS}

First, demographics on school aged children with official decision of SEN is reported. Enrollment rates are shown below.

\section{School aged children with SEN}

Students with SEN among the total school aged children are not equally distributed. Each country has different rates. As shown in Figure 1, Scotland, Lithuania, Belgium (Flemish speaking community) and Slovakia are the EU zones with more relative pupils with SEN respectively. That does not mean that they have more students with SEN than others. Similar rates can be found out of the Union, being Iceland an example. There are also EU member states with rates under $3 \%$ of children diagnosed with special needs (see Luxembourg and Sweden), but the normal situation is a rate above 5\%.

Generally, there are more students with official SEN in ISCED 2. Coinciding with the higher SEN rates, Lithuania, Belgium and Slovakia have also the greater imbalance between ISCED 1 and 2. In countries that only belong to the Schengen area, Iceland has the more imbalanced rates and Norway is more dissimilar between ISCED levels than the majority of the EU.

Data from Belgium (French speaking community) on school aged children was not available. This zone comprises $90 \%$ of the Brussels-Capital region plus the Walloon region, minus the children of the German-speaking municipalities.

\section{Students with SEN in separate classes}

Separating some pupils from the others in special classes could be an inclusive indicator inside mainstream schools. Even so, it really depends on the educational services that children who are separated would receive in mainstream classes. The point is whether the students with SEN have the major benefit in mainstream classes or not. Assuming that regular classes could be prepared for giving the appropriate educational services when needed, the rates on students with SEN in separate classes have been reported (Figure 2). However, this remark should be kept in mind.

Separate special classes in mainstream schools do not exist neither in Belgium nor in Malta. In Italy non-disabled students are not separated from pupils with SEN in mainstream schools. As for Germany, this is covered by data from special schools, so data in separated classes is missing. Special classes do also exist in the Netherlands, but there is no central registration. Sweden's data are not recorded at class level.

In Denmark and Austria there is a notably greater number of students with SEN in special classes in ISCED 2. In fact, in Denmark was found the highest rate of students in special classes. Other countries with high rates are Estonia, Finland and Slovakia, and out of the EU Switzerland. The Lowest rates were found in Croatia, Poland, Spain and England, all of them below 0,2\%. 


\section{Students with SEN enrolled in special schools}

While it is true that special separate classes could be an unclear indicator for IE, enrollment in special schools is a stronger exclusion sign. Figure 3 shows these enrollment rates. In the case of Belgium (French speaking community) data is missing for the years 2014-2015.

In the Netherlands all students with SEN are in special schools. Belgium (Flemish) and Sweden have enrollment rates above $80 \%$. Austria, Denmark, Estonia, Germany, Latvia, Luxembourg, Poland and England have rates above $40 \%$ in at least one ISCED level. Switzerland have also a rate higher than $40 \%$ being out of the EU. This is to say, European countries out of the Union also reach 4 out of 10 students with SEN in special schools.

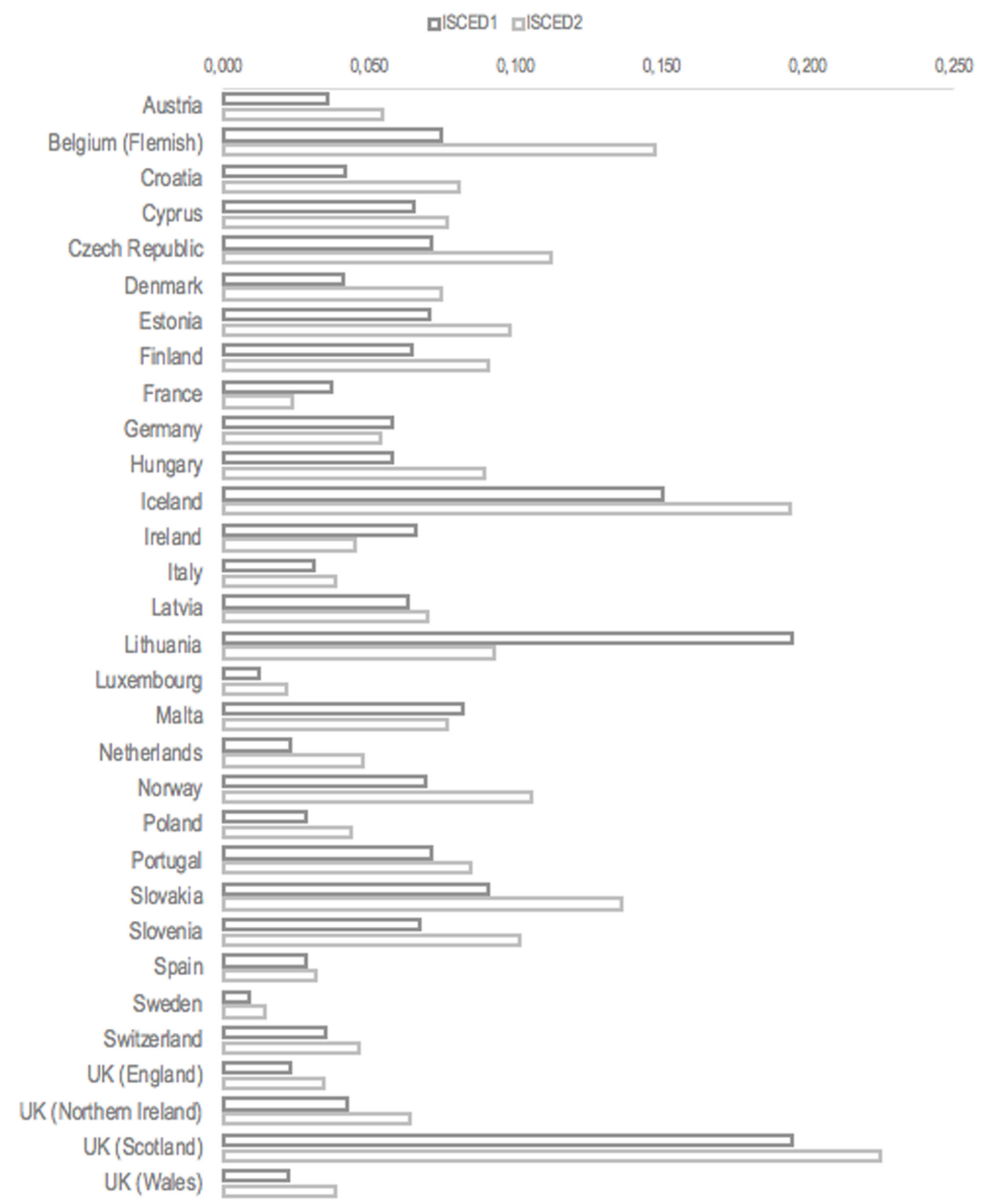

Figure 1. Students with SEN relative to the total school aged children (Var2/Var1) in 2014-2015. 


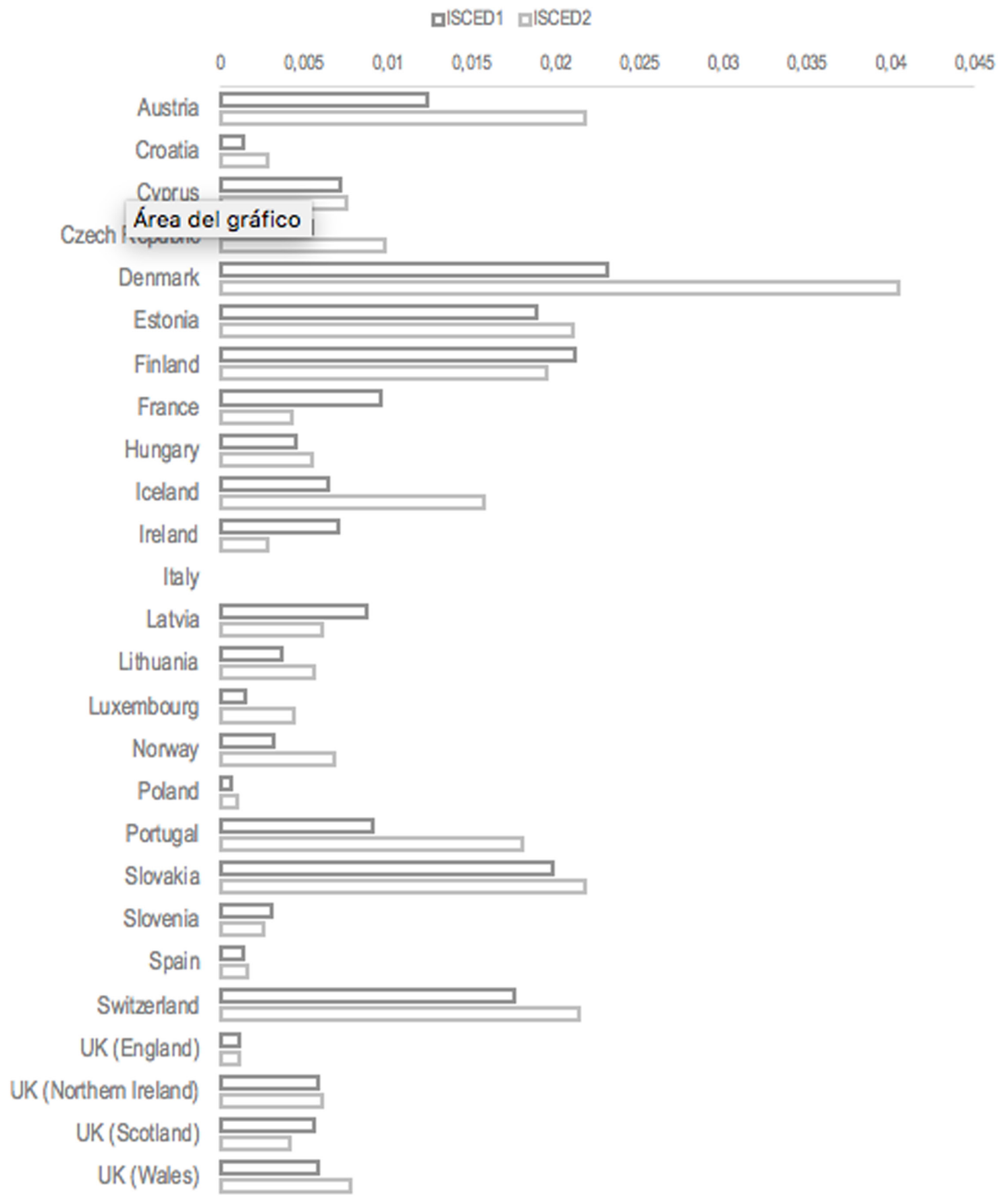

Figure 2. Students with SEN in separate classes by those in formal educational settings (Var3/Var4) in 2014-2015. 


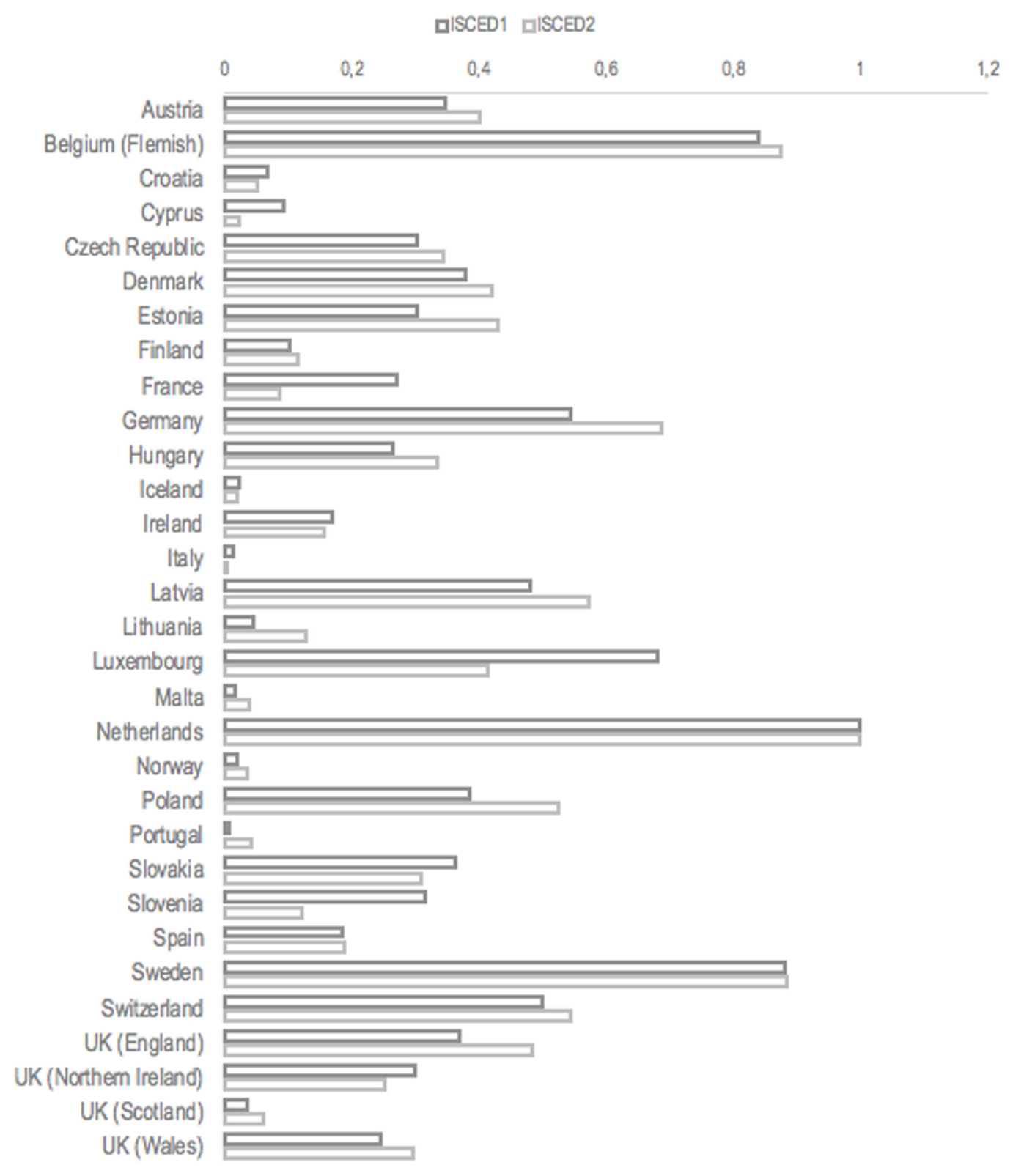

Figure 3. Students in special schools relative to the total students with SEN (Var5/Var2) in 2014-15.

Cyprus, Italy, Malta and Portugal have the lowest rates in the EU. The situation of Norway is very similar to Malta having both a notably greater number of students in ISCED 2, but Portugal have even more level differences. Out of the EU, Iceland is the country with lowest rates.

\section{DISCUSSION}

In the second decade of the 21st century we witness a scene quite similar to the first ten years. Cyprus, Italy and Portugal, among others, remain the more inclusive EU member states. Outside of the EU, Iceland and Norway maintain the lowest rates of enrollment in special schools. It draws attention the trend to geographical polarization. The highest rates of inclusion are in several meridional countries from the EU and only in a couple of northern states outside of the Union. For a reference, consult the work of Lopez-Torrijo (2009). The Netherlands, Belgium and Sweden, conversely, keep highest rates of special educational enrollment.

Although special separated classes are not a real indicator for inclusion, there are coincidences in contrast to special educational enrollment (e.g. Austria and Denmark). 


\section{Limitations}

The study is based on SEN, but not every country has the same concept of SEN. One example of complex categories is Spain, where SEN are part of a general classification called 'specific needs for educational support' (see the Law for educational quality in 2013). However, other zones only have a general category for defining SEN. Consequently, diagnosis could vary depending on the country. That suppose a validity problem when studying SEN from comparative education.

The problem began around the year 2000 with national legislation processes to classify students with SEN. All included the term disability and differentiated between SEN and learning difficulties, but some legislative texts were more complete and detailed than others. Portuguese definitions, for example, specify disorders regarding speech, language, personality, behavior and health, as well as physical, social and attitudinal barriers due to the developmental environment. Disabilities were also defined as permanent if they were cognitive, motor, visual, emotional or personality, communicative, language or speech (see Royal Decree-Law No. 6/2001, art. 10; Decree-Law No. 7/2001 of January 18th, art. 8; and Decree-Law No. 156/2002 of June 20th).

\section{European trends}

In the light of the above, it is probably reasonable to think there is a lack of convergence between the EU member states when referring to IE or, at least, to inclusive educational enrollment. When it is about the European Higher Education Area, the purpose is the European convergence. The feeling is, as said in Spain, that EU 'start the house from the roof down'. Why not to start from the beginning, from ISCED 0 and 1? This lack of convergence for inclusion in the first educational levels makes a multi-speed Europe in education, not as a political project but as an evident fact.

On the other hand, there are many countries that have politics to improve IE and to ensure that good quality education is accessible for all (e.g. Law No. 2013-595 of July 8th and Decree No. 2014-1485 of December 11th, France; Law No. 107/2015 or 'Good School' legislation, Italy; the Framework for Education Strategy 2014-2024, Malta; Decree-Law No. 93/2009 of April 16th, Decree No. 192/2014 of September 26 $6^{\text {th }}$ and Decree No. 201-C/2015 of July 10th, Portugal). An educational paradigm based on learners and learning is increasingly developing in the EU. The European Commission (2016) has improved its agenda for competency-based learning two years ago. The aim is to enhance the skills acquisition and to train safer and more active European citizens. This should lead to lifelong learning and education for all in the same way that IE leads to social inclusion. People with SEN are also citizens in the EU and are subject to it.

Along with politics, European authors still highlighting the importance of listening to the pupils' voice as a strategy for IE (Ainscow \& Messiou, 2017; Simón Rueda, Echeita, \& Sandoval Mena, 2018). Moreover, the human development and capability approach is having a worldwide impact by the hand of authors such as A. Sen and M. Nussbaum, one from India and the other from the USA. Specially, education is a relevant, influential knowledge area in this sense (Ibáñez-Martín \& Fuentes, 2017).

Another relevant point is teacher education. In most countries, teachers have an obligation to take part in continuing training according to the last report of the European Commission (2018).

\section{Educational challenges}

Defining a common concept of SEN in national legislations remains a challenge to overcome. The International Classification of Functioning, Disability and Health could be a good reference for it.

Many EU member states maintain high exclusion rates for students with SEN compared to others. European IE convergence is another challenge, taking the lowest rated countries as a model.

Legislations are ambiguous and there is a need for decentralization in Ministries' competencies for a better educational services coverage.

El is a bet today for the best European citizenship of tomorrow. 


\section{BIBLIOGRAPHIC REFERENCES}

Ainscow, M. \& Messiou, K. (2017). Engaging with the views of students to promote inclusion in education. Journal of Educational Change, 4, 1-17. doi:10.1007/s10833-017-9312-1.

Armstrong, F. (1999). Inclusion, curriculum and the struggle for space in school. International Journal of Inclusive Education, 3(1), 75-87. doi:10.1080/136031199285200.

Booth, T. \& Ainscow, M. (2002). Index for Inclusion. Developing learning and participation in schools. Bristol: Center for Studies on Inclusive Education.

European Commission. (2016). Competence frameworks: the European approach to teach and learn 21st century skills. Retrieved from: https://ec.europa.eu/jrc/en/news/competence-frameworks-european-approach-teach-and-learn21st-century-skills.

European Commission. (2018). Teaching Careers in Europe: Access, Progression and Support. Luxembourg: Publications Office of the European Union. doi:10.2797/708723.

Fulcher, G. (2015). Disabling Policies? A Comparative Approach to Education, Policy, and Disability. London: Routledge.

Ibáñez-Martín, J. A. \& Fuentes, J. L. (Eds.) (2017). Educación y capacidades. Hacia un nuevo enfoque del desarrollo humano. Madrid: Dykinson S.L.

Lopez-Torrijo, M. (2009). La inclusión educativa de los alumnos con discapacidades graves y permanentes en la Unión Europea. Revista Electrónica de Investigación y Evaluación Educativa, 15 (1), 1-20. https://www.uv.es/RELIEVE/ v15n1/RELIEVEv15n1_5.htm.

Nirje, B. (1969). The Normalization Principle and its human management implications. In R. Kugel and Wolfensberger (Eds.). Changing patterns in residential services for the mentally retarded (pp.179-195). Washington: Presidents on Mental Retardation.

Simón Rueda, C., Echeita, G., \& Sandoval Mena, M. (2018, in press). Incorporating students' voices in the 'Lesson Study' as a teacher-training and improvement strategy for inclusion. Cultura y Educación, 30, doi:10.1080/11356405.2 017.1416741.

Stainback, W. \& Stainback, S. (1992). Curriculum considerations in inclusive classrooms: Facilitating learning for all students. Baltimore: Paul H. Brookes Publishing.

United Nations. (2015). The Millennium Development Goals Report 2015. New York: UN.

Warnock, H. M. (Chm.). (1978). Special Educational Needs. Report of the Committee of Enquiry into the Education of Handicapped Children and Young People. London: Her Majesty's Stationery Office.

Wolfensberger, W. (1972). The Principle of Normalization in Human service. Toronto: National Institute on Mental Retardation. 